\title{
Canine heartworm disease in Porto Velho: first record, distribution map and occurrence of positive mosquitoes
}

\author{
Dirofilariose canina em Porto Velho: primeiro registro, mapa de \\ distribuição e ocorrência de mosquitos positivos \\ Guilherme Maerschner Ogawa ${ }^{1 *}$; Edson Neves da Cruz²; Príscila Nayara Araújo Cunha²; \\ Luís Marcelo Aranha Camargo ${ }^{1}$
}

\begin{abstract}
${ }^{1}$ Departamento de Parasitologia, Instituto de Ciências Biomédicas 5 - ICB-5, Universidade de São Paulo - USP, Monte Negro, RO, Brasil
${ }^{2}$ Laboratório de Genética, Faculdade de Biologia, Centro de Ensino São Lucas, Porto Velho, RO, Brasil
\end{abstract}

Received June 26, 2013

Accepted August 26, 2013

\begin{abstract}
The aim of this study was to make the first report on canine heartworm disease in the state of Rondônia and confirm its transmission in this state. Blood samples were randomly collected from 727 dogs in the city of Porto Velho. The samples were analyzed to search for microfilariae and circulating antigens, using three different techniques: optical microscopy on thick blood smears stained with Giemsa; immunochromatography; and PCR. Mosquitoes were collected inside and outside the homes of all the cases of positive dogs and were tested using PCR to search for DNA of Dirofilaria immitis. Ninety-three blood samples out of 727 (12.8\%) were positive according to the immunoassay technique and none according to the thick smear method. Among the 93 positive dogs, 89 (95.7\%) were born in Porto Velho. No difference in the frequency of infection was observed between dogs raised indoors and in the yard. PCR on the mosquitoes resulted in only one positive pool. This result shows that the transmission of canine heartworm disease is occurring in the city of Porto Velho and that there is moderate prevalence among the dogs. The techniques of immunochromatography and PCR were more effective for detecting canine heartworm than thick blood smears. The confirmation of canine heartworm disease transmission in Porto Velho places this disease in the ranking for differential diagnosis of pulmonary nodules in humans in Rondônia.
\end{abstract} Brazil.

Keywords: Canine heartworm disease, Dirofilaria immitis, PCR, immunochromatography, thick blood smears,

\section{Resumo}

O objetivo deste estudo foi de registrar pela primeira vez a dirofilariose canina no estado de Rondônia e confirmar sua transmissão neste estado. Amostras de sangue de 727 cáes foram colhidas aleatoriamente na cidade de Porto Velho. As amostras foram analisadas em busca de microfilárias e antígenos circulantes usando três técnicas diferentes: microscopia ótica de gota espessa corada com Giemsa e imunocromatografia de fluxo lateral e PCR. Mosquitos foram colhidos no domicilio e peridomicílio de todos os casos de cáes positivos, estes mosquitos foram testados pela PCR na detecção de DNA de Dirofilaria immitis. Noventa e três das 727 amostras de sangue foram positivas na técnica de imunoensaio (12,8\%). Nenhuma amostra foi positiva na gota espessa. Entre os 93 cáes positivos, 89 (95,7\%) foram nascidos em Porto Velho. Nenhuma diferença na frequencia de infecção foi observada entre cães criados dentro da casa ou no quintal. O PCR dos mosquitos resultou em apenas um pool positivo. Este resultado mostra que a transmissão de dirofilariose canina está ocorrendo na cidade de Porto Velho e a frequência que ocorre nos cães é considerada moderada. As técnicas de imunocromatografia e PCR são mais eficazes na detecção de dirofilariose comparadas a gota espessa. A confirmaçáo de transmissáo de dirofilariose canina em Porto Velho, coloca esta doença no ranking de diagnóstico diferencial de nódulos pulmonares em seres humanos em Rondônia.

Palavras-chave: Dirofilariose canina, Dirofilaria immitis, PCR, imunocromatografia, gota espessa, Brasil.

\footnotetext{
*Corresponding author: Guilherme Maerschner Ogawa

Departamento de Parasitologia, Instituto de Ciências Biomédicas 5 - ICB-5,

Universidade de São Paulo - USP, Rua Franscisco Prestes 1234, Setor II,

CEP 76888-000, Monte Negro, RO, Brazil

e-mail: guilherme@icbusp.org
} 


\section{Introduction}

Heartworm filariasis is a parasitic disease of worldwide distribution for which the etiological agent is a filarial nematode worm named Dirofilaria immitis (Leidy, 1856). In its adult stage, this worm produces microfilaria through sexual reproduction. The transmission is caused by mosquitoes that act as intermediate hosts.

The species $D$. immitis has cosmopolitan distribution and may also parasitize humans (CANCRINI; GABRIELLI, 2007). The adult forms of $D$. immitis feed on blood components and live for several months or years. They can be found in the right ventricle and pulmonary arteries of dogs, frequently causing coughing, dyspnea and weakness, followed by ascites due to right ventricular failure, anorexia, dehydration and weight loss (SEVIMLI et al., 2007). The pathogenicity of this species varies according to the number of adult worms. It is possible to find between one and 150 adult worms per host. They may reach sexual maturity in their occasional hosts, which include wolves, coyotes, foxes, various cats (including urban cats), mustelids, bears, beavers, raccoons, rabbits, deer, otters, penguins, horses, wild primates and humans (MANFREDI et al., 2007). In humans, the larvae do not complete the life cycle. In such cases, the final-stage larvae settle in the lungs, causing nodules that are usually diagnosed as tumors or tuberculosis (WATTS et al., 1999).

Canine heartworm disease is usually found in tropical and subtropical regions (LOK, 1988). In the tropics, mosquitoes can reproduce throughout the year, due to the high temperatures and rain profile. Many cases of canine heartworm have also been reported in temperate regions, probably due to introduction of dogs from endemic areas (BROWN et al., 2012). The prevalence rates have a tendency to be higher in coastal regions or close to large rivers. However, several autochthonous cases were recently reported in regions with different climatic and geographic characteristics (MITERPÁKOVÁ et al., 2008; TRAVERSA et al., 2010).

In Brazil, so far, canine filariasis has been reported in 15 states in all regions of the country. According to Bendas et al. (2007), the national prevalence is around $2 \%$, although some studies have found prevalences as high as 46\% (AHID et al., 1999).

With increasing migration due to the construction of two hydroelectric power plants, favorable geographic and climatic characteristics and the existence of high densities of Culex quinquefasciatus, the municipality of Porto Velho has all the favorable conditions for occurrences of canine heartworm transmission.

Our objective was to make the first report on occurrences of canine heartworm in Rondonia, estimate the prevalence of this disease in dogs and register occurrences of $D$. immitis in mosquitoes, thus confirming its transmission in this state.

\section{Methods}

The municipality of Porto Velho ( $8^{\circ} 44^{\prime} 58.80^{\prime \prime} \mathrm{S}$ and $63^{\circ} 52^{\prime}$ $46.55^{\prime}$ W) has 428,527 inhabitants and an area of $34,082 \mathrm{~km}^{2}$ (Figure 1) (IBGE, 2012). It is the capital and the largest municipality in the state of Rondônia, located in the western Brazilian Amazon region, on the right bank of the Madeira River. According to the
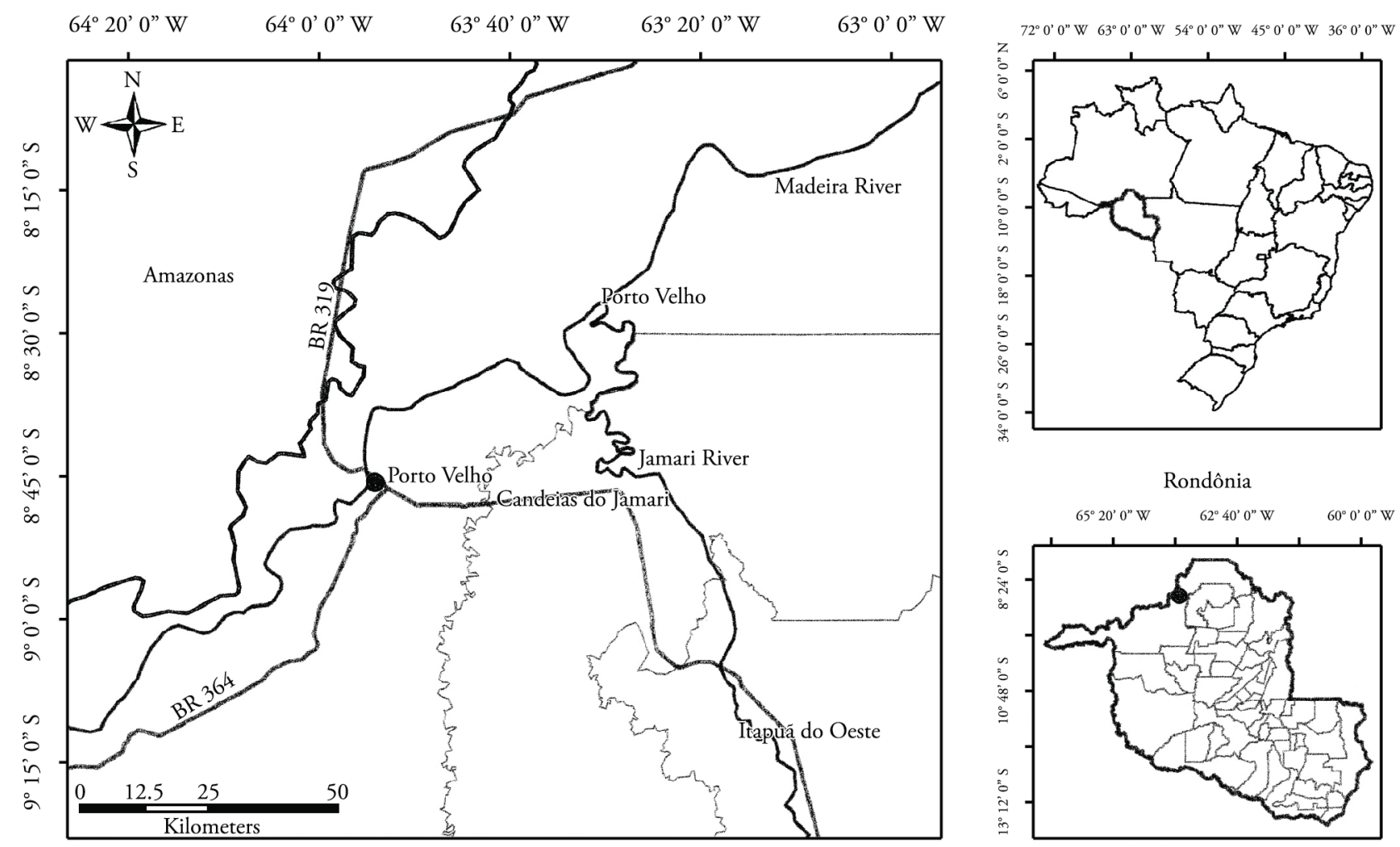

Figure 1. State of Rondônia and urban area of Porto Velho, on left bank of the Madeira river, Brazil. 
Köppen classification, the climate is defined as Aw: tropical rainy with an average annual temperature of $27^{\circ} \mathrm{C}$.

The minimum sample size was defined as 543 dogs. It was calculated using the EpiInfo software, with a significance level of $97 \%$, considering an estimated prevalence of $11 \%$ and a total canine population of 20,000 dogs. This estimated prevalence was based on studies on heartworm prevalence in nearby cities (Cuiaba in central-western Brazil and Coari in northern Brazil) (SILVA et al., 2008). The size estimate for the dog population was based on data provide by the Porto Velho Zoonosis Center. Samples were randomly collected during a local government rabies vaccination campaign in September 2010. Eleven sites for blood collection were chosen in the urban area of Porto Velho. The sites had fairly similar numbers of dogs (data based on the 2009 rabies vaccination campaign) and covered all regions of the urban area of Porto Velho. A total of 727 blood samples were collected on September 4, 2010.

The blood samples were examined for the presence of microfilaria, circulating antigens and nucleic acid segments. A sample of 2-3 mL of blood was collected from each dog, from the cephalic vein. The dogs were immobilized and a noseband was used. Immediately after the blood had been collected, it was placed in a test tube with EDTA anticoagulant. The test tubes with blood were stored in an icebox during the collection day and were subsequently stored in a refrigerator in the laboratory.

Two methods were used for examining the blood samples: microscopy on thick blood smears and the lateral flow immunochromatographic technique (Heartworm Anigen BioNote, Inc., 2-9, Seogu-dong, Hwaseong-si, Gyeonggi-do, Korea (445-170)). One drop of fresh blood was placed on a microscope slide and was dried and labeled. In the laboratory, the blood was stained with Giemsa and then examined under a 100x microscope. The immunoassay was carried out in accordance with the manual. The kit used was capable of detecting antigens of adult males and females with $94.4 \%$ sensitivity and $100 \%$ specificity and no cross-reaction with Dipetalonema reconditum. The modified Knott method or polycarbonate membrane filtration were not used because the blood was frozen right after collection in order to preserve the DNA for PCR. PCR was performed four months later, individually on all positive samples (immunoassay) and on pools of negative samples. The frequency of occurrence of heartworms was related to age, sex, place of birth, address (latitude and longitude), travels and the place in which the dogs lived (in open or closed areas).

Mosquitoes were collected using suction apparatus (Castro's collector) after positive cases had been detected in dogs. These collections were carried out at the homes and in the surroundings of all the index cases. In areas close to these homes, the authors searched for mosquitoes in wetlands with deposits of organic matter, open sewers and culverts.

The insects were preserved in isopropyl alcohol for molecular diagnostics. After taxonomic identification, individuals were separated in two subsamples: head and body (thorax + abdomen). For molecular analysis, pools containing 10 individuals were separated according to species, body part (head or thorax + abdomen), date and place of collection.
Detection of $D$. immitis DNA in mosquitoes and blood was carried out using species-specific primers: forward Diro (5'-ACGTATCTGAGCTGGCTCAC-3') and reverse Diro (5’ATGATCATTCCGCTTACGCC-3') (INVITROGEN') (WATTS et al., 1999). Blood examinations were performed as described by Vera et al. (2011), and mosquito analyses followed the protocol developed by Rocha (2007).

Correlations between positive blood findings and dog characteristics were calculated by means of the chi-square test with $95 \%$ significance level.

Over the weeks the followed the sample collections, each home was georeferenced using a Garmin GPS device. From the GPS data, a map was made using the Terra View version 4.2 software. Kernel density statistical analysis was performed. To generate the kernel map, 250 column parameters for events were used, with a quartic function algorithm and adaptive radius.

The results from the mosquito PCR were analyzed using the maximum likelihood estimate (Poolscreen software) (KATHOLI et al., 1995).

\section{Ethical clearance}

This work was approved by the Animal Experimentation Ethics Committee, under number 1667/2009, School of Veterinary Medicine, University of São Paulo.

\section{Results}

Seven hundred and twenty-seven blood samples were collected (Table 1). Of these, $12 \%$ were positive in immunoassay and $10 \%$ were positive in the PCR test $\left(\mathrm{x}^{2}=0.7513, \mathrm{p}=0.193\right)$, with no statistical difference. No samples that were negative in the immunoassay test were positive in the PCR test.

There was homogeneous distribution of cases across the different age brackets $\left(x^{2}=0.722, p=0.696\right)$. When divided by gender, the sample was balanced, such that $53.5 \%$ were males $\left(x^{2}=1.12, p=0.05\right)$. When the analysis focused on the place where the dogs lived (living indoors in the household, or living in the yard), the differences between positive individuals were $26.9 \%$ and $73.1 \%$ respectively $\left(x^{2}=0.41, p=0.05\right)$. Considering the dogs' birthplace, $95.7 \%$ of the positive dogs had been born in and had never left Porto Velho. Four positive individuals were born in other cities or states such as Pernambuco (northeast) and São Paulo and Rio de Janeiro (both in the southeast).

The kernel density map revel a hotspot in the northern area of the city (Figure 2), suggesting that this was a high prevalence area.

A total of 3115 mosquitoes were collected (Table 2). Out of the total number of pools analyzed, only one was positive. The

Table 1. Positive and negative results founded using Immunoassay, PCR and Thick blood smears for the detection of D. immits antigen, DNA and microfilaria.

\begin{tabular}{lccc}
\hline & Immunoassay & PCR & Thick blood \\
\hline Positive & $93(12 \%)$ & $73(10 \%)$ & $0(0 \%)$ \\
Negative & $634(88 \%)$ & $654(90 \%)$ & $727(100 \%)$ \\
\hline
\end{tabular}




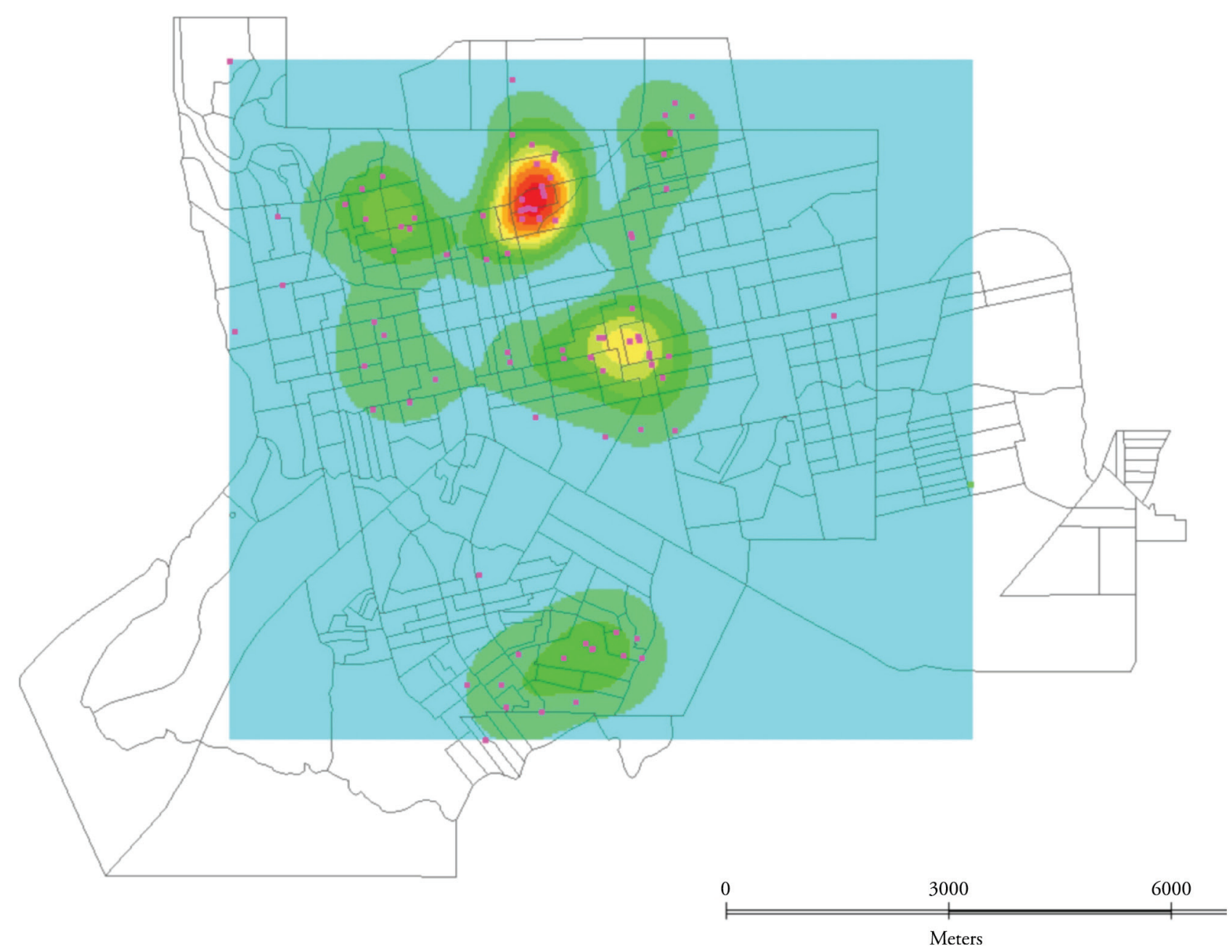

Figure 2. Statistical analysis with hot spot (red area) in the northern area of the city of Porto Velho (pink dots = positive cases).

Table 2. Mosquitoes collected in Porto Velho and analyzed by PCR.

\begin{tabular}{lccc}
\hline & Positive & Negative & Total \\
\hline C. quinquefasciatus & 1 & 2971 & 2972 \\
Aedes aegypti & 0 & 142 & 142 \\
Anopheles triannulatus & 0 & 1 & 1 \\
Total & 1 & 0 & 3115 \\
\hline
\end{tabular}

positive pool was composed of bodies (thorax + abdomen) of C. quinquefasciatus. The band in the gel was compatible with the 378 base pairs of the positive control (see supplementary data). Statistical analysis on the maximum likelihood estimate in the Poolscreen software resulted in an estimated infection prevalence of $0.32 \%$ with a confidence interval of $0.09 \%$ to $1.6 \%$ at a $95 \%$ significance level.

\section{Discussion}

The number of positive dogs was moderate. The heartworm parasite is still most frequent in coastal areas, but the huge influx of people (and their pets) to developing cities such as Porto Velho may be the cause of the spread of heartworm disease within the country (ARAUJO et al., 2003; BENDAS et al., 2007; LABARTHE et al., 1998; REIFUR et al., 2004; TRAVERSA, 2012). The lower prevalence in areas far from the coast may be linked to the vectors. On the other hand, we may only be observing the introduction of the disease into Rondônia, which would explain the moderate prevalence.

The results showed that the majority of the positive dogs shared the following characteristics: they were young, lived in open areas and were born in Porto Velho. The negative dogs had the same characteristics, and this is probably the reason why the statistical tests did not produce results with statistical significance. One of the positive dogs was from São Jose do Rio Preto (state of São Paulo), a city for which no data on the presence of $D$. immitis is available. The other positive cases were from known transmission areas. The fact that the majority of the positive dogs had been born in Porto Velho and had never left it, and also the fact that the PCR technique showed positive results for the mosquitoes, indicates that transmission of $D$. immitis was occurring in this city.

The map with the hotspot was overlain on a map that indicated the region's sanitation system (water provision and sewage collection) (see supplementary data).

These parameters were used because they have an influence on heartworm transmission (BROWN et al., 2012). Only $2 \%$ of 
Porto Velho has sewage collection (IBGE, 2012). In the hotspot area, the most common sewage disposal method was to dig holes in the ground in the backyard of the home. Despite this, other city areas without a hotspot had the same characteristics. There were some city areas with sampling bias, which occurred because these areas were forested or unoccupied (see supplementary data).

The immunoassay diagnosis results were interpreted as positive, but with low amounts of antigens (according to the test manual). This result was interpreted from a band that became colored when positive, and the intensity of this color indicated the amount of antigen detected. In this present study, this band always presented weak staining. The antigen detected in the immunoassay could be found for up to six months after the worm's death. This antigen was produced by the majority of both male and female adult worms, and its presence in the blood was independent of microfilaria production. This result may explain why microfilaria were not found in the blood smear, since the small amount of antigen indicated that there were small numbers of adult worms and, consequently, lower microfilaria concentration. A small number of microfilaria might be eliminated by the host's organism or might not appear in the amount of blood used in other tests. The low microfilaria load may also explain the discrepancy between the immunoassay/ PCR methods and the blood smear technique.

The prevalence of positive mosquitoes shown the PCR technique was similar to the findings of studies on naturally infected vectors in Brazil. Other studies have found prevalences of between 0.1 and 0.5\% (BRITO et al., 2001; LEITE, 2005; ROCHA, 2007). The positive result strengths the hypothesis of local transmission.

\section{Conclusions}

We concluded that Dirofilaria immitis occurs in Porto Velho at a moderate rate. This result reinforces the probability that heartworm was introduced into Porto Velho through dogs from cities where $D$. immitis is endemic. The immunoassay technique and the PCR method are more efficient for detecting D. immitis infections in dogs than the blood smear technique. We emphasize the importance of $C$. quinquefasciatus in relation to heartworm transmission. This confirmation of heartworm transmission in Porto Velho also includes this disease among the ranking for differential diagnosis of pulmonary nodules in humans in Rondônia.

\section{Acknowledgements}

INAGEMP - National Institute of Population Medical Genetics (CNPq grant number 573993/2008-4) for the support provided for this project, and especially to Marcelo Zagonel for mapping the area. Dr. Norma W. Labarthe for providing adult worms for positive controls for the PCR; and Mateus Duarte Ribeiro for the kernel map. FAPESP - Financial support; procedural number 2008/10813-0. FAPEAM - Scholarship for the first author.

\section{References}

Ahid SMM, Lourenço-de-Oliveira R, Saraiva LQ. Dirofilariose canina na Ilha de Sáo Luís, Nordeste do Brasil: uma zoonose potencial. Cad
Saúde Pública 1999; 15(2): 405-412. PMid:10409793. http://dx.doi. org/10.1590/S0102-311X1999000200025

Araujo RT, Marcondes CB, Bastos LC, Sartor DC. Canine dirofilariasis in the region of Conceição Lagoon, Florianópolis, and in the Military Police kennel, São José, State of Santa Catarina, Brazil. Vet Parasitol 2003; 113(3-4): 239-242. http://dx.doi.org/10.1016/S03044017(03)00077-3

Bendas AJR, Paiva JP, Doria MI, Mendes-de-Almeida F, Branco AS, Silvano DRB, et al. Ocorrência de Dirofilaria immitis no entorno de um caso diagnosticado na Zona Sul do Rio de Janeiro/RJ, Brasil. Acta Sci Vet 2007; 35(S2): 678-679.

Brito AC, Vila-Nova MC, Rocha DAM, Costa LG, Pinheiro de Almeida WA, Viana LS, et al. Prevalência da filariose canina causada por Dirofilaria immitis e Dipetalonema reconditum em Maceió, Alagoas, Brasil. Cad Saúde Pública 2001; 17(6): 1497-1504. PMid:11784911. http://dx.doi. org/10.1590/S0102-311X2001000600034

Brown HE, Harrington LC, Kaufman PE, McKay T, Bowman DD, Nelson CT, et al. Key factors influencing canine heartworm, Dirofilaria immitis, in the United States. Parasit Vectors 2012; 5: 245. PMid:23111089 PMCid:PMC3523980. http://dx.doi.org/10.1186/1756-3305-5-245

Cancrini G, Gabrielli S. Vectors of Dirofilaria nematodes: biology, behaviour and host/parasite relationships Mappe Parassitologiche 2007; 8: 47-58.

Instituto Brasileiro de Geografia e Estatística - IBGE. Censo 2010 [online] 2010 [cited 2012 jan 21]. Available from: http://www.censo2010. ibge.gov.br/painel/?nivel=st

Katholi CR, Toé L, Merriweather A, Unnasch TR. Determining the prevalence of Onchocerca volvulus infection in vector populations by polymerase chain reaction screening of pools of black flies. $J$ Infect Dis 1995; 172(5): 1414-1417. PMid:7594692. http://dx.doi. org/10.1093/infdis/172.5.1414

Labarthe N, Serrão ML, Melo YF, De Oliveira SJ, Lourenço-de-Oliveira R. Potential vectors of Dirofilaria immitis (Leidy, 1856) in Itacoatiara, oceanic region of Niterói municipality, state of Rio de Janeiro, Brazil. Mem Inst Oswaldo Cruz 1998; 93(4): 425-432. PMid:9711329. http:// dx.doi.org/10.1590/S0074-02761998000400001

Leite LC. Mosquitos (Diptera, Culicidae) vetores potenciais de Dirofilaria Immitis (Leidy, 1856) em Guaratuba, Paraná [Tese]. Curitiba: Universidade Federal do Paraná; 2005.

Lok JB. Dirofilaria sp.: taxonomy and distribution. In: Boreham PFL, Atwell RB. Dirofilariasis. Boca Raton: CRC Press; 1988. p. 82-84.

Manfredi MT, Di cerbo A, Genchi M. Biology of filarial worms parasitizing dogs and cats. Mappe Parassitologiche 2007; 8: 23-26.

Miterpáková M, Antolová D, Hurníková Z, Dubinský P. Dirofilariosis in Slovakia - a new endemic area in Central Europe. Helminthologia 2008; 45(1): 20-23. http://dx.doi.org/10.2478/s11687008-0003-6

Reifur L, Thomaz-Soccol V, Montiani-Ferreira F. Epidemiological aspects of filariosis in dogs on the coast of Paraná state, Brazil: with emphasis on Dirofilaria immitis. Vet Parasitolol 2004; 122(4): 273-286. PMid:15262005. http://dx.doi.org/10.1016/j.vetpar.2004.05.017

Rocha RT. Padronização da Reação de PCR para Deteç̧ão de Dirofilaria immitis (Leidy, 1856) e Determinação da Taxa de Infecção em Mosquitos Coletados na Ilha de Santa Catarina [Dissertação]. Florianópolis: Universidade Federal de Santa Catarina; 2007. 
Sevimli FK, Kozan E, Bülbül A, Birdane FM, Köse M, Sevimli A. Dirofilaria immitis infection in dogs: unusually located and unusual findings. Parasitolol Res 2007; 101(6): 1487-1494. PMid:17659383. http://dx.doi.org/10.1007/s00436-007-0665-x

Silva AMA, Almeida KS, Sousa JJN, Freitas FLC. Dirofilariose Canina no município de Coari, Amazonas, Brasil. Arch Vet Scie 2008; 13(2): 145 150 .

Traversa D, Cesare A, Conboy G. Canine and feline cardiopulmonary parasitic nematodes in Europe: emerging and underestimated. Parasit Vectors 2010; 3: 62. PMid:20653938 PMCid:PMC2923136. http:// dx.doi.org/10.1186/1756-3305-3-62
Traversa D. Pet roundworms and hookworms: A continuing need for global worming. Parasit Vectors 2012; 5: 91. PMid:22574783 PMCid:PMC3418564. http://dx.doi.org/10.1186/1756-3305-5-91

Vera LJS, Basano SA, Camargo JSAA, França AK, Ferreira RGM, Casseb AA, et al. Improvement of a PCR test to diagnose infection by Mansonella ozzardi. Rev Soc Bras Med Trop 2011; 44(3): 380-382. PMid:21779677.

Watts KJ, Courtney CH, Reddy GR. Development of a PCR and probe-based test for the sensitive and specific detection of the Dog Heartworm, Dirofilaria immitis, in its mosquito intermediate host. Mol Cell Probes 1999; 13(6): 425-430. PMid:10657147. http://dx.doi. org/10.1006/mcpr. 1999.0270 